\title{
Determinants of Smallholder Farmers' Cash Crop Production Decision and Its Effect on Household Income in Humbo District, Wolaita Zone, Ethiopia
}

\author{
Hailu Sodana Teka Tamirat Guja \\ Department of Economics, Wolaita Sodo University, PO Box 138, Wolaita Sodo, Ethiopia
}

\begin{abstract}
Producing market oriented crops at smallholder farmer level is very important for improving the rural household's income. The aim of this study was identifying factors that determine smallholder farmers' cash crop production decision and its effect on household income in Humbo District, Wolaita Zone, Ethiopia. Data for the study was collected from 254 rural households using interview schedule. Multi-stage sampling technique was used as sampling technique. The data was analyzed using descriptive statistics and Heckman's two stage model. Accordingly, the study identified cash crops such as pepper, cabbage, onion, and cotton are dominantly produced by smallholder farmers; male headed households are more likely producing these crops relative to female headed; and farmers at the age range of 31 and 64 years are more likely producing than at other age category. Lack of timely supply of agricultural inputs, higher prevalence of crop diseases, fluctuation of market price, and perishable nature of crops are identified as the major crop problems in the study area. Based on the Binary Logistic Regression result, sex, experience on farming activities, access to extension service, off-farm income, and distance from farm land to water sources were significantly determining cash crop production decision. On the other side, Multiple Linear Regression model result revealed as access to credit, off-farm income, number of oxen, landholding size, and education level were significantly determining rural household income. Accordingly: the government should intervene in timely provision of modern agricultural inputs and create favorable linkage between farmers and research centers. The credit institutions should be accessible to ensure timely purchase of agricultural inputs.
\end{abstract}

Keywords: Smallholder farmers, participation, income, cash crops, Heckman two stage;

DOI: $10.7176 / \mathrm{EJBM} / 12-25-05$

Publication date:September $30^{\text {th }} 2020$

\section{INTRODUCTION}

Smallholder agriculture sector plays a major role in generating household income, reducing food insecurity and in overall the economic growth by providing employment opportunities for unemployed, main source of GDP and foreign exchange earnings (CSA, 2016). According to the report of ministry of Agriculture and rural development of Ethiopia in 2015, more than $95 \%$ of countries agricultural output is produced by smallholder farmers. The priorities of development policy and the country's strategy gives high focus on producing market oriented cash crops to improve the household income at smallholder farmer level. Cash cropping system for market sale motivates farmers to transform subsistence farming system to commercial farming system (Adam et al, 2016).

Vegetable is one of the sub-sectors in crop production and needs only a small area of land, minimal capital outlay and provides access to a valuable food under subsistence conditions. Usually smallholders intensively cultivate vegetables on their gardens. This helps them in a number of ways: - it provides them regular supply of vegetables at a low cost and provides a more varied diet for their farm family (Nichols and Hilmi, 2009). Vegetable crops play the vital role in the country's GDP through exporting to different countries around the world. For example, it accounts about $12.3 \%$ of the total export value share, following coffee and sesame cash crops in Ethiopia (FAO, 2015). According to ERCA, (2013), Ethiopia exported about 220,213 tons of vegetables and generated about $\$ 438$ million in a single year. The country has favorable climatic conditions for the production of vegetable crops in all agro ecological zones and its production increases from time to time. For example, the area under vegetable crops grown by smallholder farmers increased from 351,000 hectares in 2010 to 397,000 hectares in 2013 production year. Its total production is also increased from 2.4 million tons in 2010 to 4.5 million tons in 2013 (CSA, 2013). This figure indicates as vegetable sector has potential to involve smallholder farmers under its production. Despite, the available potential and opportunities, majorities of smallholder farmers are not actively producing cash crops and their participation level is far below the available potential. This low participation of smallholder farmers on cash crop production has off course negative effects on rural household income and in turn it may affect the overall country's economic development (Gurung B. et al; 2012)..

Almost all farmers in the study area are smallholder farmers. They produce crops at subsistence level and are left with only few cash endowments to save and invest in other farming and non-farming activities. A previous study such as Bekabil et al, 2016; EHDA (2012); and Kumilachew et al, (2014) were undertaken at national level and focused on only analyzing its export oriented production, marketing aspects, and the common production related problems. But they didn't address factors that affect the smallholder farmers' cash crop production decision 
and its effect on their household income. Therefore, this study was motivated to fill this gap by analyzing factors that affect smallholder farmers' cash crop production decision and its effect on household income in Humbo district, Wolaita Zone, Ethiopia. The specific objectives of the study are: (1) to identify major limiting problems that hinder smallholder farmers from producing cash crops in Humbo District, Wolaita Zone; (2) to analyze the determining factors that affect smallholder farmers' cash crop production decision; and (3) to examine the effect of cash crop production on rural household income in the district.

\section{MATERIALS AND METHODS}

\section{Description of the Study Area}

This research was conducted in Humbo district, Southern Ethiopia. It is found in Wolaita Zone and its weather condition is $70 \%$ low land and 30\% Moderate. Mixed farming system which involves crop production and livestock rearing is the main stay of rural households in the district. The area is suitable for the production of many cash crops such as coffee, cereals, fruits, root crops, fiber crops, and vegetables (pepper, cabbages, onions, carrots, and tomatoes) at smallholder farmers' level. Animal husbandry is complementary to crop production, and the livestock populations of the district include cattle, sheep, goats, and poultry (CSA, (2016).

Research design: The study employed mixed research design meaning both qualitative and quantitative research approaches were used. It provides the opportunity for presenting a greater diversity of divergent views (John Creswell, 2014).

\section{Data Sources and Methods of data collection}

The data for this study was obtained from both primary and secondary sources. The primary data was collected through interview schedule from 254 randomly selected rural farming households. The primary data is supplemented by secondary data that was gathered from published and unpublished documents.

\section{Sampling Design}

The total sample size was determined by using Cochran's sample size formula (Cochran, 1977) and then adjusted for the total population of the study area using minimum sample size formula of Fowler (2001):

$$
\text { no }=\frac{\mathrm{z}^{2} \mathrm{pq}}{\mathrm{e}^{2}}
$$

Where: - $\mathrm{n}_{\mathrm{o}}$ is the total sample size of the study derived from equation, $\mathrm{Z}^{2}$ value for selected alpha level of 0.025 in each tail (for $95 \%$ degree of confidence) $=1.96$, e is the desired level of precision (i.e., the margin of error) $=$ $6 \%, p$ is the estimated proportion of an attribute, $q=1-p$, and $(p) .(q)=$ estimate of variance $=0.25$.

$$
\text { no }=\frac{1.96^{2} *(0.5) *(0.5)}{0.06^{2}}=257
$$

Therefore, Cochran's (1977) correct formula was used to calculate the final sample size of the study area.

$$
\mathrm{n}=\frac{\text { no }}{1+\left(\frac{\mathrm{no}-1}{\mathrm{~N}}\right)}
$$

Based on the number of the total households in the sampling frame $(20,223)$, the formula equated and reached a minimum of $\mathbf{2 5 4}$ respondents from participant and non-participant farmers.

$$
\mathbf{n}=\frac{257}{1+\frac{257-1}{20,223}}=\frac{257}{1+0.0127}=\frac{257}{1.0127}=\mathbf{2 5 4}
$$

Multi-stage (purposive, \& probability) sampling technique was employed to obtain necessary information from both categories. In first stage, out of 39 rural kebeles, five were purposively selected based on their existing potential. In the second stage, total number of household heads was stratified into two as cash crop producers and non-producers. Then sample respondent households were randomly selected from each stratum using simple random sampling technique.

\section{Econometric Model specification}

This study involved "analyzing the determining factors of farmers' decision to participate on cash crop production" and "analyzing the effect of this participation on household income". Hence, Heckman's two stage model was applied as it can simultaneously show the participation decision on production of cash crops and its effect on household income.

\section{Model 1: Analyze the participation decision to produce cash crops}

In the first stage, binary logistic model was employed as it is dichotomous in nature which takes 0 or 1 depending on whether the households produce cash crops or not (D. Gujarati (2009). The standard Binary Logistic model with several determining variables is commonly written as: -

$\mathrm{Pi} /(1-\mathrm{Pi})=\left(1+\mathrm{e}^{\mathrm{Zi}}\right) /\left(1+\mathrm{e}^{-\mathrm{Zi}}\right)=\mathrm{e}^{\mathrm{Zi}}$.

Where: $\mathrm{Pi}$ is the probability that a farmer will not participate on cash crop production; 1-Pi is the probability that 
a farmer produce cash crops; e is the base of the natural logarithm. Now, Pi / (1 - Pi) is simply the odds in favor of producing cash crops: - the ratio of the probability that a farmer will not produce cash crops to the probability that they produce cash crops. The empirical analysis of binary logistic regression was specified as follows:

FPVP $=\alpha+\beta_{1}$ Sex $+\beta_{2}$ Age $+\beta_{3}$ Educ $+\beta_{4}$ Plab $-\beta_{5}$ IAlab $+\beta_{6}$ Lhsize $+\beta_{7}$ EXP $-\beta_{8}$ DSTWTR $+\beta_{9}$ Ox $-\beta_{10}$ OffI $+\beta_{11}$ NMHI $+\beta_{12}$ Credit $+\beta_{13}$ EXT

Where FPVP = dichotomous variable representing smallholder farmers' decision to produce cash crops. Parameters; $\alpha_{0}, \alpha_{1}, \alpha_{2}, \alpha_{3}, \alpha_{4},--\beta_{\mathrm{k}}$ represent coefficients for the row vectors to be estimated.

\section{Model 2: Analyze the effect of cash crop production on household income}

In the second stage, the effect of cash crop production on total household income was analyzed using Multiple Linear Regression models as household income takes any value in birr. The equation of income from cash cropping can be expressed as:

$Y i=X i \beta+\varepsilon i$.....

Where Yi is the individual household's income from cash cropping, it is observable for the participants in the production and unobservable for the non-participant households that is why we use Heckman sample selection. Xi is vectors of observable factors that affect income from producing cash crops and $\varepsilon i$ is the error term.

The empirical analysis of this part was specified as follows:

$\mathrm{Yi}=\alpha+\beta_{1}$ Sex $+\beta_{2}$ Age $+\beta_{3}$ Educ $+\beta_{4}$ Plab $-\beta_{5}$ IAlab $+\beta_{6}$ Lhsize $+\beta_{7}$ EXP- $\beta_{8}$ DSTWTR $+\beta_{9} \mathrm{Ox}+\beta_{10} \mathrm{OffI}+\beta_{11} \mathrm{NMHI}$ $+\beta_{12}$ Credit $+\beta_{13}$ EXT

Study Variables

Household decision to produce cash crops (FPVP): it is treated as dummy variable that takes 1 if the farmer is cash crop producer at least during 2019/20 cropping season and 0 other wise.

Household Income (Yi):- is the individual household's income and is treated as continue variable that takes any value in birr.

Determining variables: in this study, different variables were introduced in to the models as determining variables of farmers' decision to produce cash crops and household income. They were treated according to their nature i.e. sex (Sex) treated as dummy variable [0 if female headed, 1 if male headed], age (Age) treated as categorical $[1=18-30$ years, $2=31-45$ years, $3=46-64$ years, $4=>64$ years], education level (Educ) as categorical $[1=<5$ grade complete, $2=5-8$ grade complete, $3=9-12$ grade complete, $4=$ higher class complete $]$, number of productive family labor (Plab) as continue variable takes any value in number, number of inactive family members (IAlab) as continue variable, landholding size (Lsize) as categorical $[1=<0.5 \mathrm{ha}, 2=0.5-1 \mathrm{ha}, 3=1.1-1.5 \mathrm{ha}$, $4=>1.5 \mathrm{ha}$ ]; number of oxen owned (Oxen) as continue variable that takes any value in number, experience on farming activities (EXP) treated as continue variable in years, income from off-farm activities (OFFI) treated as continue variable in birr, distance from farm land to water sources (DSTWTR) treated as continue variable in kilo meter, net monthly income of the household (NMHI) treated as continue in birr, timely contact with extension agents (EXT) treated as dummy variable [0 if no access to extension service, and 1 if they have better access], and access to credit service (CRDT) as dummy [0 if no access to credit service, and 1 if they have better access to it].

\section{RESULTS AND DISCUSSION}

DESCRIPTIVE ANALYSIS

Demographic characteristics: - out of 254 total household heads considered, 127 were cash crop producers and 127 were not producers. Accordingly, $80 \%$ of them are male headed and $20 \%$ are female headed. To see this on producer-non-producer basis, $91.3 \%$ of cash crop producers are male headed and $8.7 \%$ are female headed whereas $68.5 \%$ of non-producers are male headed and $31.5 \%$ are female headed. This confirms that males are actively participating on crop production than women. On the other side, $17 \%$ of the respondents are at age category of between 18 and 30 years, 30\% are between 31 and 45, 50\% are between 46 and 64, and only 3\% of them are at old-age category of $>64$ years. To see this fact on producer-non-producer basis, $3.9 \%$ of cash crop producers are at age category of between 18 and 30 years, $21.5 \%$ are between 31 and 45 years, $70.7 \%$ are between 46 and 64 years, and $3.9 \%$ of them at age category of $>64$ years whereas $30.7 \%$ of non-producers are at the age category of between 18 and 30 years, $37.8 \%$ are between 31 and 45 years, $28.3 \%$ are between 46 and 64 years, and $3.2 \%$ are at old-age category of $>64$ years. This result confirms that most of the farmers at moderate age category of 31 to 64 years and are actively participating on cash crop production than farmers at other age categories (Table 1). 


\begin{tabular}{|c|c|c|c|c|c|c|c|c|}
\hline \multirow{4}{*}{ Variable } & \multirow{4}{*}{ Category } & & & & & & & \\
\hline & & \multirow{3}{*}{$\begin{array}{l}\text { Description and } \\
\text { Codes }\end{array}$} & \multicolumn{6}{|c|}{ Response rate on respondent category } \\
\hline & & & \multicolumn{2}{|c|}{ Total } & \multicolumn{2}{|c|}{ Participants } & \multicolumn{2}{|c|}{ Non-part. } \\
\hline & & & Freq. & $\%$ & Freq. & $\%$ & Freq. & $\%$ \\
\hline \multirow[t]{2}{*}{ Sex } & \multirow[t]{2}{*}{ Dummy } & $0=$ female headed & 51 & 20 & 11 & 8.7 & 40 & 31.5 \\
\hline & & $1=$ male headed & 203 & 80 & 116 & 91.3 & 87 & 68.5 \\
\hline \multirow[t]{4}{*}{ Age } & \multirow[t]{4}{*}{ Categorical } & $1=18-30$ years & 44 & 17 & 5 & 3.9 & 39 & 30.7 \\
\hline & & $2=31-45$ years & 75 & 30 & 27 & 21.5 & 48 & 37.8 \\
\hline & & $3=46-64$ years & 126 & 50 & 90 & 70.7 & 36 & 28.3 \\
\hline & & $4=$ above 64 years & 9 & 3 & 5 & 3.9 & 4 & 3.2 \\
\hline
\end{tabular}

Source: Field Survey, May, 2020

Socio-economic factors: - Education level of household head was also taken as one of the variables that determine farmers' decision to produce cash crops. Accordingly, 22\% of the household heads attended below 5 grade, $58 \%$ completed primary classes (5-8 grades), 13\% of them completed secondary classes (9-12 grades), and only 7\% of them were higher class complete. To see this frequency distribution on producer-non-producer basis, $6.3 \%$ of cash crop growers attended below 5 grade, $79.5 \%$ were primary class complete, $11 \%$ were secondary class complete, and $3.2 \%$ of them were higher class complete whereas $38.6 \%$ of non-producer farmers attended below 5 grade, $35.4 \%$ were primary class complete, $15 \%$ were secondary class complete, and $11 \%$ of them were higher class complete (Table 2). Land is the basic factor for the production of agricultural activities. Accordingly, $27 \%$ of the households own $<0.5$ hectare, $54 \%$ own between 0.5 ha and 1 hectare, $17 \%$ own between 1.1 ha and 1.5 ha, and only $2 \%$ of them own $>1.5$ hectare of total land under crop. To see this fact on producer-non-producer basis, $9.4 \%$ of cash crop producers own $<0.5$ hectare, $60 \%$ own 0.5 ha to 1 hectare, $30 \%$ own 1.1 ha to 1.5 hectare, and only $2 \%$ of them own $>1.5$ hectare whereas $45 \%$ of non-growers own $<0.5$ hectare, $48 \%$ own 0.5 to 1 hectare, $4 \%$ own 1.1 to 1.5 hectare, and $3 \%$ of them own $>1.5$ hectare of total land. This result implies that majorities of the sampled farmers own less than 1 hectare of land under crop (Table 2).

Number of livestock owned is considered as another variable to determine the participation decision of farmers on cash crop production. Accordingly, 58\% of the respondents own small number of oxen (no or 1 ox), $30 \%$ of them own 2 oxen, and $12 \%$ of them own more than 2 oxen. To see this figure on producer-non-producer basis, $4.7 \%$ of cash crop producers have no ox, $38.6 \%$ own 1 ox, $41 \%$ own 2 oxen, and $15.7 \%$ of them own more than 2 oxen whereas $41 \%$ of non-producers have no ox, 30.7\% own 1 ox, $19.7 \%$ own 2 oxen, and $8.6 \%$ own more than 2 oxen. Access to timely contact of extension service is also a variable that determine the household decision to produce cash crops. Accordingly, $69 \%$ of the respondent farmers have better access to get advises on proper land management system, performing irrigation facilities, and conserving their land and $31 \%$ of them have no access to it. To see this figure on producer-non-producer basis, $90.5 \%$ of cash crop growers are better accessing timely extension service and $9.5 \%$ of them have no access to it whereas $47.3 \%$ of non-growers have better access to extension services and $52.7 \%$ of them have no access to it (Table 2).

According to the descriptive result, $25 \%$ of the respondent households have no access to get timely credit service and $75 \%$ of them have better access to credit services. On producer-non-producer basis, $79.5 \%$ of cash crop producers are better accessing credit services and $20.5 \%$ of them have no access to it whereas $71 \%$ of nonproducers are better accessing credit facilities and $29 \%$ of them have no access to it. Monthly net household income is another important variable and $16 \%$ of the households have $<500$ birr monthly income, $18 \%$ have from 500 to 1500 birr, $20 \%$ have from 1501 to 3500 birr, $21 \%$ have 3501 to 5000 birr, and only $25 \%$ of them have monthly income of $>5000$ birr. On producer-non-producer basis, 3.2\% of cash crop producers have monthly household income of $<500$ birr, $11 \%$ have between 500 and 1500 birr, $18 \%$ between 1501 and 3500 birr, $27 \%$ have between 3501 and 5000 birr, and $40.8 \%$ of them earn beyond 5000 birr whereas $29 \%$ of non-cash crop producers earn < 500 birr, 24\% between 500 and 1500 birr, 22\% between 1501 and 3500 birr, 15\% between 3501 and 5000 birr, and $10 \%$ of them earn beyond 5000 birr monthly household income (Table 2). This confirms that households who produce cash crops have higher monthly income than those do not produce cash crops. 
Table 2: Socio-economic factors

\begin{tabular}{|c|c|c|c|c|c|c|c|c|}
\hline \multirow[t]{3}{*}{ Variable } & \multirow[t]{3}{*}{ Category } & \multirow[t]{3}{*}{ Descriptions } & \multicolumn{6}{|c|}{ Response rate on respondent category } \\
\hline & & & \multicolumn{2}{|c|}{ Total } & \multicolumn{2}{|c|}{ Participants } & \multicolumn{2}{|c|}{ Non-part. } \\
\hline & & & Freq. & $\%$ & Freq. & $\%$ & Freq. & $\%$ \\
\hline \multirow{4}{*}{$\begin{array}{l}\text { Education } \\
\text { Level of } \mathrm{HH} \\
\text { head }\end{array}$} & \multirow[t]{4}{*}{ categorical } & $1=$ below grade 5 & 57 & 22 & 8 & 6.3 & 49 & 38.6 \\
\hline & & $2=5-8$ grade & 146 & 58 & 101 & 79.5 & 45 & 35.4 \\
\hline & & $3=9-12$ grade & 33 & 13 & 14 & 11 & 19 & 15 \\
\hline & & $4=$ above 12 grade & 18 & 7 & 4 & 3.2 & 14 & 11 \\
\hline \multirow[t]{4}{*}{ Land size } & \multirow[t]{4}{*}{ Categorical } & $1=<0.5$ hectare & 69 & 27 & 12 & 9.4 & 57 & 45 \\
\hline & & $2=0.5$ up to $1 \mathrm{ha}$ & 137 & 54 & 76 & 60 & 61 & 48 \\
\hline & & $3=1.1$ ha up to $1.5 \mathrm{ha}$ & 43 & 17 & 38 & 30 & 5 & 4 \\
\hline & & $4=>1.5$ hectare & 5 & 2 & 1 & 0.6 & 4 & 3 \\
\hline \multirow{4}{*}{$\begin{array}{l}\text { Oxen } \\
\text { ownership }\end{array}$} & \multirow[t]{4}{*}{ Continue } & 0 (no ox) & 58 & 23 & 6 & 4.7 & 52 & 41 \\
\hline & & 1 & 88 & 35 & 49 & 38.6 & 39 & 30.7 \\
\hline & & 2 & 77 & 30 & 52 & 41 & 25 & 19.7 \\
\hline & & $>2$ oxen & 31 & 12 & 20 & 15.7 & 11 & 8.6 \\
\hline \multirow{2}{*}{$\begin{array}{l}\text { Timely } \\
\text { contact }\end{array}$} & \multirow[t]{2}{*}{ dummy } & $0=$ no access & 79 & 31 & 12 & 9.5 & 67 & 52.7 \\
\hline & & $1=$ better access & 175 & 69 & 115 & 90.5 & 60 & 47.3 \\
\hline \multirow{2}{*}{$\begin{array}{l}\text { Access to } \\
\text { credit }\end{array}$} & \multirow[t]{2}{*}{ dummy } & $0=$ no access & 63 & 25 & 26 & 20.5 & 37 & 29 \\
\hline & & $1=$ better access & 191 & 75 & 101 & 79.5 & 90 & 71 \\
\hline \multirow{5}{*}{$\begin{array}{l}\text { Net } \\
\text { Monthly } \\
\text { household } \\
\text { income }\end{array}$} & \multirow[t]{5}{*}{ Categorical } & $1=<500$ birr & 40 & 16 & 4 & 3.2 & 36 & 29 \\
\hline & & $2=500-1500$ birr & 45 & 18 & 14 & 11 & 31 & 24 \\
\hline & & $3=1501-3500$ birr & 51 & 20 & 23 & 18 & 28 & 22 \\
\hline & & $4=3501-5000$ birr & 53 & 21 & 34 & 27 & 19 & 15 \\
\hline & & $5=>5000$ birr & 65 & 25 & 52 & 40.8 & 13 & 10 \\
\hline
\end{tabular}

Source: Field Survey, May, 2020

\section{Major Constraints that limit Cash Crop Production}

Both cash crop producer and non-producer respondent farmers mentioned lack of timely supply of agricultural inputs (improved seed varieties, motor pumps, other agricultural implements), higher prevalence of crop diseases, fear of market related problems, perishable nature of the crops especially vegetables, higher cost of inputs, and erratic nature of rain fall as the constraints that limit the participation decision of smallholder farmers on cash crop production. The supply of improved seed is not on time and mostly it is after the time of cropping season. So, farmers forced to buy low quality seeds from local markets even at higher prices. Crop diseases such as pests, termites, insects, weeds, and grasshopper are identified as commonly prevailing diseases to attack vegetables especially cabbage, onion, and pepper. Even though there are different ways to control these diseases, using chemicals is widely used by smallholder farmers at the time of disease outbreaks.

\section{ECONOMETRIC RESULTS OF THE STUDY}

Before estimation of parameters, explanatory variables were checked for the existence of multicollinearity, heteroscedasticity and normality problems. Accordingly, after checking and assuring for their no existence, parameters of the model were estimated.

\section{Econometric analysis of smallholder farmers' production decision of Cash Crops}

Informed by these test results, binary logistic model was carried out and variables such as sex of household head, experience on farming activities, income from off-farm activities, access to timely extension contact, and distance from farm land to water sources were identified as they significantly determine smallholder farmers' decision to produce cash crops (Table 3). 
Table 3: The summarized regression results of the model for decision of smallholder farmers to produce cash crops

\begin{tabular}{|l|l|l|l|l|l|}
\hline \multicolumn{5}{|c|}{ Decision to produce cash crops } & Odds ratio \\
\hline Explanatory variables & Coef. & SE & $Z$ & P $\mathbf{Z}$ & \\
\hline SEX & & & & & \\
\hline AGE & .0786457 & .7674525 & 3.10 & 0.008 & $.8302464^{* * *}$ \\
\hline EDUC & -.0399177 & .0594267 & -0.67 & 0.502 & .9520576 \\
\hline PLAB & -.083799 & .09491 & -0.88 & 0.377 & .9177357 \\
\hline IALAB & .2166704 & .2897619 & 0.75 & 0.455 & 1.24534 \\
\hline LSIZE & .1685369 & .2217082 & 0.76 & 0.447 & 1.208709 \\
\hline EXP & 1.784415 & 1.82106 & 0.98 & 0.327 & 5.573322 \\
\hline OXEN & .5104736 & .0862196 & 5.92 & 0.000 & $1.681578^{* * *}$ \\
\hline OFFI & .1293473 & .4671423 & 0.28 & 0.782 & 1.157447 \\
\hline EXT & -1.32683 & .6440486 & -2.06 & 0.039 & $.1882259^{* *}$ \\
\hline CRDT & .0003701 & .0001319 & 2.81 & 0.005 & $1.000417 * * *$ \\
\hline NMHI & -.4019158 & .5641625 & -0.71 & 0.476 & .563915 \\
\hline DSTWTR & -.2400558 & .9614203 & -0.25 & 0.803 & .7350235 \\
\hline cons & -1.09309 & .6584902 & -2.66 & 0.007 & $.3975214^{* * *}$ \\
\hline $\begin{array}{l}\text { Number } \text { of obs. }=254 \\
\text { LR chi2(14) }=254.38\end{array}$ & -.8467449 & 2.193381 & -0.39 & 0.699 & .8302464 \\
\hline
\end{tabular}

Source: own survey result, 2019/20

Sex of household head (Sex): -Binary Logistic regression result revealed that sex of household head was significantly and positively determining farmers' decision to produce cash crops at 1 percent significance level. That is, odd of being participated on cash crop production of male headed households is .8302464 times higher than that of female headed (Table 3). This tells that male headed households are more likely participating on cash crop production than female headed households in Humbo district. This result is consistent with the finding of Vargas Ruth and Vigneri Marcella, 2011 in East Africa.

Experience on farming activities (EXP):- it was also significantly and positively determining the participation decision of smallholder farmers on cash crop production at 1 percent significance level. That is, for a one year increase in experience of the farmers on their farming activities, odds of being participated on cash crop production of the smallholder farmers increases by 1.681578 units (Table 3 ). One reason for this could be that those farmers who invested more times on their farm may gain more practical skills and knowledge which could be re-used in their next farming activities. This reduces the mistakes a farmer makes in production process and improves its performance on arming activities as experienced farmers know better which crops to grow, when to grow, and which inputs to use or not use. The result is consistent with the finding of J. Kanyua et al, (2015) in Gatanga district of Kenya.

Off-farm income activities (OFFI):- it is demonstrated that households in the study area generate additional income from selling livestock products, running small businesses, selling fire wood (charcoal), renting pack animals, participating in cobble stone /sand/ mining, and daily labor works. Accordingly, it was identified that income from these activities significantly and positively determining the participation decision of smallholder farmers on cash crop production at 5 percent significance level. That is, for a one $\%$ increase in additional income from participating on off-farm activities, odds of being participated on crop production of smallholder farmers decreases by .1882259 units (Table 3). This tells that those farmers who more participate in off-farm activities are less likely produce crops than farmers do not participate in off-farm activities. The reason could be that households who participate on off-farm activities may have little time to participate in on-farm activities. The finding by Anselm et al. (2010) in Nigeria supports this fact.

Access to timely extension contact (EXT): it was also identified that access to extension service statistically significant at 1 percent significance level to determine the participation decision of smallholder farmers to produce cash crops. That is, the relative odds of producing cash crops of smallholder farmers who better accessing timely extension contact is 1.000417 times higher than those who don't have access to it suggesting a positive correlation between access to extension service and cash crop production. This result is comparable with the finding of Kumilachew et al (2014) in Kombolcha woreda, Ethiopia.

Distance from farm land to water sources (DSTWTR):- this variable was also found to determine the smallholder participation decision on cash crop production negatively and significantly at $1 \%$ significance level. That is, for a one Kilo Meter increase in distance from farm land to water sources, odds of smallholder farmers' decision to produce cash crops decreases by .3975214 units (Table 3). The possible justification could be households who are farther from the water sources may incur additional costs to access their farm i.e. it may require 
motor pumps to bring water from water sources to farm land and higher opportunity cost of the time lost in travelling to and from a farm lands. The finding by Emana et al (2015) Ethiopia supports this result.

\section{Econometric analysis of the effect of producing cash crops on rural household income}

This part describes the effect of participating in cash crop production on rural households' income given their participation. Accordingly, the results of Heckman two-stage selection model after correcting for the selection bias revealed that access to credit service, income from off-farm activities, number of oxen, landholding size, and education level of household head were significantly determining rural household income in the study area (Table 4).

Table 4: Results of OLS estimation of participation effect on household income

\begin{tabular}{|l|l|l|l|l|}
\hline \multicolumn{5}{|c|}{ Effect of participation decision on rural household income } \\
\hline Variables & Coef. & Std. Err. & T & P $>\mathrm{t}$ \\
\hline DSTWTR & -.3486061 & .264128 & -0.07 & 0.947 \\
\hline IALAB & -4.329552 & 1.26567 & -0.91 & 0.365 \\
\hline CRDT & 2.23391 & .36551 & 2.34 & $0.021^{* *}$ \\
\hline EXT & 5.611891 & 1.237946 & 1.06 & 0.291 \\
\hline OFFI & .1521847 & 4.470989 & 4.03 & $0.003^{* * *}$ \\
\hline OXEN & 12.13249 & .171146 & 5.59 & $0.000^{* * *}$ \\
\hline EXP & .4492585 & .4030366 & 1.11 & 0.267 \\
\hline LSIZE & 4.14355 & 1.68424 & 4.23 & $0.000^{* * *}$ \\
\hline PLAB & 1.630595 & 1.95974 & 0.83 & 0.407 \\
\hline EDUC & .478599 & .7510419 & 3.64 & $0.006^{* * *}$ \\
\hline AGE & -.0896402 & .4316078 & -0.21 & 0.836 \\
\hline SEX & 1.950853 & 5.373423 & 0.36 & 0.717 \\
\hline $\begin{array}{l}\text { Number of observations } \\
\text { Prob }>\text { F }=0.0000\end{array}$ & 254 & R-squared $=0.518$ & \\
\hline
\end{tabular}

Source: own survey result, $2019 / 20$

Access to credit service (CRDT): - in this study, access to credit service has a positive effect on the rural household income and statistically significant at 5 percent significance level. That is, rural farming households who better accessing credit service generate 2.23391 times higher income than those who don't have access to credit service (Table 4). This is explained as timely provision of credit service enables smallholder farmers to timely purchase agricultural inputs such as oxen, fertilizers, improved seeds, chemicals, motor pumps and others for the production of crops and this in turn increases their income. This result is comparable with the finding of Anselm et al. (2010) in Nigeria.

Income from off-farm activities (OFFI):- it was identified that generating additional income from off-farm activities significantly and positively affecting the total household income at $1 \%$ significance level. That is, for a one percent increase in additional income from participating on off-farm activities, the total rural household income increases by .1521847 units (Table 4). This tells that those farmers who more participate in off-farm activities are more likely generating higher income than those who do not participate in off-farm activities. The finding by Adam B et al. (2016) in Southern Kenya supports this fact.

Number of oxen owned (OXEN): - Ox is one of the major assets of agricultural smallholder farming households. It is found to have a significant and positive effect on income of rural households at 1 percent significance level. That is, for a one percent increase in extra more ploughed ox, household income increases by almost 12 percent suggesting a positive correlation between oxen ownership and household income (Table 4). This implies that households that own larger number of ploughed oxen are more likely to raise their farm income as they can cultivate and sow their land at the right time to increase their farm production. The result is consistent with the finding of Firdissa, (2016) in Jimma Geneti Woreda, Ethiopia.

Landholding size (LSIZE): Land is also a major asset for smallholder farmers for the production of crops. It was identified as landholding size is significantly and positively determining rural household income at 1 percent significance level. That is, for a one hectare increase in the size of cultivated land, rural household income increases by 4.14355 percent. (Table 4) The result implies that the availability of land for crop production increases rural household income. This finding is comparable with the finding of Rehima M., et al, (2013) in southern state of Ethiopia.

Education level (EDUC): - it is also identified that education level of household head was significantly and positively determining rural household income at 1 percent significance level. That is, rural households whose heads attend higher classes ( $>12$ grade) generate .478599 times higher income than those households whose heads are illiterate (Table 4). This may be due to the fact that information, knowledge, and skills are prerequisites for farmers to adopt and apply new agricultural technologies. The finding by Anselm et al. (2010) in Nigeria confirms this fact. 


\section{CONCLUSION AND POLICY IMPLICATIONS}

The objective of this study was to analyze factors that affect smallholder farmers' cash crop production decision and its effect on household income in Humbo district, Wolaita Zone, Ethiopia. Accordingly, the study found that cash crops such as pepper, cabbage, onion, and cotton are dominantly produced for market sale by smallholder farmers; male headed households are more likely to produce market oriented crops relative to female headed; and farmers at the age range of 31 and 64 years are more likely producing cash crops than farmers at other age category. The study identified that lack of timely supply of agricultural inputs, higher prevalence of crop diseases, fear of market related problems such as fluctuation of market price, perishable nature of the crops especially vegetables, and higher cost of inputs are some of the limiting problems that hinder smallholder farmers from producing cash crops. Based on the binary logistic model result, sex of household head, having better experience on farming activities, and timely accessing extension service were positively determining the smallholder farmers' cash crop production decision whereas generating higher income from off-farm activities and farthest distance from farm land to water sources were negatively determining their production decision. Based on the Multiple Linear Regression model result, having better access to credit, generating additional income from off-farm activities, owning large number of oxen, holding large sized land, and attending higher level education were significantly and positively determining rural household income. Accordingly, the authors strongly recommend that government and concerned NGOs: - (1) should intervene in timely provision of modern agricultural inputs such as improved seeds, fertilizers, extension services, motor pumps, chemicals, and others and create favorable linkage between farmers and research centers. (2) The credit institutions also should be accessible to ensure timely purchase of agricultural inputs.

\section{REFERENCES}

Adam B., Yasin E.and Mengistu K.,(2016) Determinants of smallholder commercialization of horticultural crops in Gemechis District, West Hararghe Zone, Ethiopia. Afric J Agri Res., Vol. 9, pp. 310-319, January, 2014.

A Anselem et al, 2010; Challenges of Agricultural adaptation to climate change in Nigeria: a synthesis from literature. Journal of field actions, Vol.4, 2010.

Bekabil, Urgessa Tilahun. "Empirical Review of Production, Productivity and Marketability of Soya Bean in Ethiopia." International Journal of $u$ - and e-Service, Science and Technology 8, no. 1

CSA (Central Statistical Agency) (2013): Agricultural sample survey 2012/2013. Volume I, report on area and production of major crops, meher season, statistical bullettin 532, Addis Ababa, Ethiopia. Available on line at http://www.csa.gov.et(Accessed on April 19, 2014/.

CSA. "Central Statistical Agency." Demographic and Health Surveys Report. Addis Ababa, October 2016.

Cochran, (1977): Sampling Techniques (3th Edition) William G. Cochran

Damodar N. Gujarati (2009). Basic Econometrics, fifth Edition.

EHDA (Ethiopian Horticulture Development Agency)(2011, 2012: Exporting Fruit and Vegetables from Ethiopia: Assessment of development potentials and investment Options in the Export Oriented fruit and vegetable Sector. Addis Ababa, Ethiopia.

Emana, Bezabih; Afari-Sefa, Victor; Dinssa, F Fekadu; Ayana, Amsalu; Balemi, Tesfaye; Temesgen, Milkessa;. "Chaterterization and Assessment of Vegetable Production and Marketing System in the Humid Tropics of Ethiopia." Quarterly Jounral of International Agriculture 54, no. 2 (2015): 163-187.

(ERCA) Ethiopian Revenue and custom Authority, 2013): Export of 2013. Addis Ababa. Downloadable at http://www.erca.go.et accessed on April 19, 2014.

FAO "Food and Agriculture Organizations (2015). "Fruits and vegetables for Health Report of joint with WHO.

Firdissa Birru Goshu,2016"Determinants of smallholder farmers' participation decision in teff production: Evidence from Horo and Jimma Geneti Woreda, Ethiopia.ISSN 2224-607X(paper) ISSN 2225-0565(online). Vol.6, No.10,2016

Floyd J. Fowler, (2001): Survey Research Methods, Applied social Research Methods Series Volume 1: Third Edition

Gurung G; Koirala P, Pande D, Basnet D, Kale O., (2012) "Promoting Rural livelihoods through Riverbed vegetable farming in the Tarai region of Nepal. " Journal of International Development and Cooperation 18, no. 4(2012):113-121. (error, is added 2 times)

John W. Creswell, (2014). Research Design, Qualitative, Quantitative and Mixed Methods Approaches; Fourth Edition; University of Nebraska-Lincoln

J. Kanyua, K.Gicuru, K. Siboko and R. Wanjiru, 2015 Factors influencing profitability of diversified cash crops farming among Smallholder Tea farmers in Gatanga district, Kenya. journal of economics and sustainable development, vol.6, No.3, 2015

Kumilachew A., Mengistu K., and Fekadu G., 2014. Risks in vegetables production from the perspective of smallholder farmers: The case of Kombolcha Woreda, Oromia region, Ethiopia. science publishing group (http://www.sciencepublishinggroup.com/j/aff) 
Nichols M. and Hilmi M. " Rural infrastructure and Agro-industries Division; Food and Agriculture Organization of the United Nations. Rome 2009.

Rehima M, Belay K, Dawit A and Rashid S, 2013 Factors affecting farmers' crops diversification: Evidence from SNNPR, Ethiopia.

Vargas Ruth and Vigneri Marcella, 2011. Mainstreaming gender sensitivity in cash crop market supply.ESA working paper No.11-08. Agricultural development economics division, FAO 